\title{
Artificial gametes from stem cells
}

\author{
Inmaculada Moreno', Jose Manuel Míguez-Forjan², Carlos Simón ${ }^{1,2,3}$ \\ 'Department of Research and Development, Igenomix S.L., Paternam; ${ }^{2}$ Fundación Instituto Valenciano de Infertilidad (FIVI), Valencia, Spain; \\ ${ }^{3}$ Department of Obstetrics and Gynecology, Stanford University School of Medicine, Stanford, CA, USA
}

The generation of artificial gametes is a real challenge for the scientific community today. In vitro development of human eggs and sperm will pave the way for the understanding of the complex process of human gametogenesis and will provide with human gametes for the study of infertility and the onset of some inherited disorders. However, the great promise of artificial gametes resides in their future application on reproductive treatments for all these people wishing to have genetically related children and for which gamete donation is now their unique option of parenthood. This is the case of infertile patients devoid of suitable gametes, same sex couples, singles and those fertile couples in a high risk of transmitting serious diseases to their progeny. In the search of the best method to obtain artificial gametes, many researchers have successfully obtained human germ cell-like cells from stem cells at different stages of differentiation. In the near future, this field will evolve to new methods providing not only viable but also functional and safe artificial germ cells. These artificial sperm and eggs should be able to recapitulate all the genetic and epigenetic processes needed for the correct gametogenesis, fertilization and embryogenesis leading to the birth of a healthy and fertile newborn.

Keywords: Artificial gametes; Cell-based therapy; Gametogenesis; Germ cells; Human germ cell specification; Pluripotent stem cells; Primordial germ cell-like cells

\section{Relevance of artificial gametes}

Artificial gametes are mature germ cells (sperm and eggs) generated in vitro by specification and maturation of their natural diploid precursors, the primordial germ cells (PGCs), or by directed differentiation of pluripotent cells to the germ-cell lineage. These cells, after completing meiosis, should be able to undergo fertilization and subsequent embryogenesis, transmitting their genetic and epigenetic information to the next generation as their in vivo counterparts do [1].

The generation of human artificial gametes are of outstanding in-

Received: Jun 16, 2015 · Revised: Jun 18, 2015 · Accepted: Jun 18, 2015 Corresponding author: Carlos Simón

Fundación IVI, Parc Científic Universitat de València, CICatedrático Agustín Escardino $n^{\circ}$ 9. Edificio 3, 46980- Paterna, Spain

Tel: +34-963903305 ext.18530-18102 Fax: +34-963902522

E-mail:Carlos.Simon@ivi.es, csimonv@stanford.edu

*This research was supported by Grant PTQ-13-06133 to IM. KY Cha Award in Stem Cell Technology to CS.

This is an Open Access article distributed under the terms of the Creative Commons Attribution Non-Commercial License (http://creativecommons.org/licenses/by-nc/3.0/) which permits unrestricted non-commercial use, distribution, and reproduction in any medium, provided the original work is properly cited. terest in the context of assisted reproductive medicine as they would offer a clinical solution for different patients seeking for in vitro fertilization (IVF) treatments, but they would also help to understand the complex mechanism of human gametogenesis that is currently poorly studied due to the technical and ethical limitations associated to the use of those human samples for research.

\section{Clinical use of artificial gametes \\ 1) Infertile couples}

Infertility is a clinical condition that concerns 15\% of couples in reproductive age. Among them, $28 \%$ are affected by different pathologies causing absence of available gametes [2] including patients with premature ovarian failure [3], post-menopausal women, and male patients suffering from non-obstructive azoospermia or any other pathology leading to the absence of either spermatozoa or elongated spermatids available to be used in assisted reproductive treatments (Guidelines on Male Infertility. European Association of Urology 2009. Available from: http://www.uroweb.org/fileadmin/tx_eauguidelines/2007/Full/Male_Infertility.pdf). These pathologies produce infertility in up to $1 \%$ of women [4] and $0.63 \%$ of men [5] in the 
general population. For these patients the use of donated gametes, either ovum or sperm, is mandatory. Also couples bearing genetic disorders with a high risk of transmitting serious diseases to their progeny or patients with repeated IVF failure usually go to donated gametes to improve their chances to have a healthy baby. Another group of patients interested in the therapeutic use of artificial gametes in assisted reproductive treatments rely on patients that have overcome a cancer in their early infancies and are infertile due to the anticancer treatments received while they were unable to cryopreserve their own gametes [6-12].

\section{2) Fertile couples}

On the other hand, people who are fertile would also benefit from the use of artificial gametes, as same sex couples, single parents and post-menopausal women. For these kind of patients, donor gametes are the sole option to have their own genetic related descendants. Within this group, same sex couples would be able to have their own artificial gametes, either sperm or eggs, independently of their sex, so that both partners of the couple could be genetic parents of the newborn.

\section{Scientific use of artificial gametes}

The generation of artificial gametes will not only provide therapeutic advantages for those people wishing to have genetically related progeny and for whom donor gametes is their only current chance to have babies, but it will also provide new knowledge in the field of germ cell biology. The in vitro generation of human gametes will help to understand the biological process of germ cell specification and maturation. Nowadays, developmental studies regarding human germ cell development are performed by using animal models due to the lack of available human samples. However, it has been widely shown that gametogenesis is species-specific, and although the general developmental process is conserved among mammals, there are some differences that hampers the direct translation of the knowledge acquired in mouse into human $[13,14]$. The main interests on artificial gametes production are focused on the establishment of a reproducible method to generate fully committed haploid sperm and oocytes that will offer large amounts of cells at different stages of germ cell formation and that will be the basis for further experiments. This is of outstanding interest for the understanding of the different molecular and cellular events that take place during normal human gametogenesis and subsequent study of human disease models related to germ cell defects or other diseases producing infertility and lack of functional gametes. If obtaining artificial gametes from disease patients, the mechanisms of some kinds of infertility could be unraveled and thus potential treatments could be developed for those patients devoid of functional gametes. Also, by com- bining artificial gamete production from stem cells with new gene editing techniques, the correction of diseases could be potentially carried out in those patients suffering from inherited genetic disorders, so that their offspring would not suffer, nor transmit the disease to their progeny. On the other hand, the information obtained from in vitro gametogenesis models could be used to avoid the maturation of germ cells, leading to new and effective contraceptives.

As an example of the scientific strength of artificial gamete production from pluripotent cells, Dominguez and collaborators have recently published a study in which induced pluripotent stem cells from Turner syndrome individuals were differentiated in vitro into germ cell-like cells (GCLC) and compared to GCLC from control individuals [15]. The results of this work showed that aneuploidies in $\mathrm{X}$ chromosome do not impair germ cell formation but the correct dose of $X$ chromosome is critical for the maintenance or functionality of those GCLC until adulthood, uncovering the origin of infertility in Turner syndrome patients.

\section{Gametes generation: the in vivo process}

Most of the knowledge accumulated in the development of mammalian germline comes from animal models, mainly with the wellknown murine model, while the process is still poorly understood in humans.

Gametes are highly specialized cells responsible for transmitting genetic and epigenetic information through generations [1]. The differentiation between germ and somatic cells occurs very early in development when a group of mesodermal cells escape from their somatic fate during gastrulation, and is characterized by two fundamental facts: reacquisition of the pluripotency and extensive epigenetic remodeling.

Based on the mouse model, during gastrulation the founder population of primordial germ cells (PGCs) are specified by extrinsic signals driven by bone morphogenetic proteins (BMP4 and BMP8b); BMPs induce Prdm 1 and Prdm 14 expression in mouse PGCs probably through the expression of mesodermal factor $T$ (Brachyury) [16]. These events have been also observed in human PGC specification with few exceptions, such as overexpression of PRDM14 which is down-regulated in humans $[13,14]$. Tcfap $2 c$, which encodes AP2 $\gamma$, has also been described in mouse as a critical element that acts downstream of Prdm1. AP2 $\gamma$ might also be involved in the repression of somatic genes, including early mesodermal markers, such as Hoxb1 [17]. After their specification, PGCs are characterized by the expression of several pluripotency genes such as Oct4 (also known as Pou5f1), Nanog and Sox2 [18], as well as other markers such as Fragilis and Stella $[17,19]$. Again there are small differences between mice and humans, as the lack of SOX2 expression and a delay in the ex- 
pression of PRDM14 [14,20].

At the moment of their specification, PGCs are epigenetically indistinguishable from surrounding epiblastic cells, and show inherited epigenetic modifications such as DNA methylation and X chromosome inactivation that represent epigenetic barriers to totipotency acquisition in somatic tissues. PGCs begin the first wave of a profound epigenetic remodeling in order to acquire the epigenetic state necessary to form functional gametes [21]. The first epigenetic changes in PGC reprogramming take place at the histone modification level, leading to a large chromatin remodeling. These changes in histone modifications occur in parallel to an overall reduction in DNA methylation during PGC migration [21,22]. A deeper reset of methylated DNA occurs in a second wave of epigenetic remodeling events [23]. This process involves a global erasure of DNA methylation patterns, including imprinted genes, while PGCs reach a basal epigenetic state $[21,24,25]$.

\section{Artificial gametes generation: the in vitro counterpart}

With the development of in vitro models we can recapitulate human gametogenesis to understand the mechanisms behind meiotic control and the underlying cross-talk between germ cells and surrounding somatic cells. Two kinds of stem cells can be use as starting material for the generation of artificial gametes: (1) adult stem cells from both male and female gonads, and (2) pluripotent stem cells such as embryonic stem cells (ESCs), obtained by in vitro derivation of the embryonic inner cell mass [26], or induced pluripotent stem cells (iPSCs), obtained from somatic cells by overexpression of exogenous defined factors [27-29].

\section{From adult stem cells}

There are numerous adult tissues, if not all, that have the ability to regenerate themselves due to the existence of a specific population of adult stem cells with capacity for self-renewal and specification within their cell lineages [30-32]. The existence of this type of stem cells in the testis, the so-called spermatogonial stem cells (SSCs), has been widely demonstrated [33]. They are located in the basal lamina of the seminiferous tubule and are responsible for the continued production of sperm during the life of males. SSCs start to asymmetrically divide when sexual maturity is reached, giving rise to mitotically active spermatogonia, whilst also self-renewing [34-37], always under the control of a very specific microenvironment directed by Sertoli cells by building the balance between self-renewal and differentiation. It is possible to identify and purify human SSC by using different membrane markers such as a6-integrin (CD49f) and $\beta 1$ integrin, two laminin receptors [38], CD9, a basal membrane cell at- tachment protein [39] and other markers [37,40-44]. SSC culture is challenging due to the need of blocking differentiation, maintenance of long-term survival, and promoting of proliferation. Attempts of in vitro spermatogenesis demonstrate promising results in humans, where SSCs isolated from human biopsies and co-cultured with Sertoli cells have shown expression of markers for meiotic progression and haploid cell formation [45]. However they have not fared better, due in part to the need for a co-culture system that mimics the microenvironment of testicular niche. Perhaps for this reason neither fertilization nor healthy offspring have been reported to date with gametes generated by this mechanism (Table 1) [13-15, 45-58].

In the female counterpart, it is generally accepted that human ovaries contain a fixed number of non-growing follicles established before birth that decreases with female age and is depleted in menopause [59-68]. Some researchers very early on struggled against the growing dogma about the finite number of follicles and oocytes at birth [69]. In the mouse model, the existence of ovarian stem cells leading to viable offspring was first reported by Zou et al. [70] in 2009. In spite of the fact that there is no evidence of persistence of oogonia in adult human ovaries, a new idea about germinal (oogonial) stem cells in adult ovaries has been developed [71-74]. The existence of stem cells in the human ovary has been surrounded by controversy. Some works in mouse and human have described a population of rare ovarian stem cells able to generate oocytes in vitro $[55,75]$, representing an invaluable promise in regenerative medicine to treat infertile women. However, these works have been widely refuted, and some other authors consider that the presence of ovarian stem cells has been overestimated [76-79]. The ovarian stem cells are the most interesting population of cells for potential autologous de novo oogenesis and regeneration of non-functional ovaries in infertile women. In the human adult ovaries, putative ovarian stem cells (OSC) can be isolated by Fluorescence-activated cell sorting (FACS) as small rounded VASA positive-cells from the ovarian surface epithelium. These cells can grow and develop into oocyte-like cells in vivo and in vitro [55,80-82]. Interestingly there appears to be more positive results for the in vitro generation of female gametes rather to sperm (Table 1). This may be due to the greater ease to perform coculture of OSC with the surrounding somatic cells; because folliclelike structure is easier to reproduce in vitro [55]. However, this starting material is limited or even absent in infertile patients so they do not seem to be the best option for regenerative medicine purposes on female infertile patients. For this reason pluripotent stem cells (PSCs) seem to be a better option, according to its greater availability in those kind of patients.

\section{From human pluripotent stem cells (hESCs and hiPSCs)}

First evidences of in vitro germ line formation from pluripotent stem 
Table 1. Human germ cell-like cells in vitro derivation

\begin{tabular}{|c|c|c|c|c|c|c|}
\hline Origin & Derivation conditions & In vivo assays & Epigenetic features & Germ cell markers & Outcome & Reference \\
\hline $\mathrm{hESC}(\mathrm{XY}, \mathrm{XX})$ & $\begin{array}{l}\text { Adherent culture; } \\
\text { BMP4, BMP8b, RA; } \\
\text { DAZ2, DAZL, BOULE } \\
\text { overexpression }\end{array}$ & Not analyzed & $\begin{array}{l}\text { mC low global levels. } \\
\text { H19, PEG1, SNRPN, and } \\
\text { KCNQ ICR } \\
\text { hypomethylation }\end{array}$ & $\begin{array}{l}\text { PRDM1, VASA, DAZL, } \\
\text { STELLA, } ү \mathrm{H} 2 A X, \text { SYCP3 }\end{array}$ & $\begin{array}{l}\text { Germ cell-like cells } \\
\text { (1N, TEKT1, ACROSIN) }\end{array}$ & [46] \\
\hline $\begin{array}{l}\operatorname{hESC}(X X, X Y) \\
\operatorname{hiPSC}(X X)\end{array}$ & $\begin{array}{l}\text { Adherent culture; } \\
\text { BMP4, BMP8b, RA; } \\
\text { VASA overexpression }\end{array}$ & Not analyzed & H19 ICR demethylation & $\begin{array}{l}\text { PRDM1, VASA, DAZL, } \\
\text { IFITM1, GCN, GDF, } \\
\text { cKIT, PELOTA, GDF9, } \\
\text { ZP4, SYCP3, CENP-A }\end{array}$ & Germ cell-like cells & [48] \\
\hline hiPSC (XX, XY) & $\begin{array}{l}\text { BMP4, BMP8b; } \\
\text { VASA overexpression }\end{array}$ & $\begin{array}{l}\text { Transplantation } \\
\text { into mouse testis }\end{array}$ & $\begin{array}{l}\text { KCNQ10T1, PEG1, H19, } \\
\text { and H19ICR } \\
\text { hypomethylation; } \\
\text { Global demethylation; } \\
\text { 5mC to } 5 \mathrm{hmC} \\
\text { conversion }\end{array}$ & $\begin{array}{l}\text { PRDM14, VASA, } \\
\text { STELLA, NANOS2/3, } \\
\text { DAZ2, SYCP3 }\end{array}$ & Induced PGCs (2N) & [49] \\
\hline $\begin{array}{l}\text { hiPSC }(X Y) \\
\text { Y microdelections }\end{array}$ & BMP4, BMP8b & $\begin{array}{l}\text { Transplantation } \\
\text { into mouse testis }\end{array}$ & $\begin{array}{l}\text { Global DNA } \\
\text { demethylation }\end{array}$ & $\begin{array}{l}\text { PRDM1, PRDM14, } \\
\text { VASA, DAZ, STELLA, } \\
\text { IFITM3, NANOS3, } \\
\text { PLZF, UTF1, SALL4 }\end{array}$ & Induced PGCs (2N) & [50] \\
\hline $\mathrm{hESC}(\mathrm{XX}, \mathrm{XY})$ & $\begin{array}{l}\text { Embryoid body } \\
\text { formation; } \\
\text { BMP4, RA, } \\
\text { medium from NMT }\end{array}$ & Not analyzed & Not analyzed & $\begin{array}{l}\text { PGC markers: } \\
\text { CKIT, SSEA1; } \\
\text { Meiosis marker: SCYP3 }\end{array}$ & $\begin{array}{l}\text { Spermatid-like cells: } \\
\text { PRMI, 1.97, 1N DNA } \\
\text { Follicle-like structures: } \\
\text { GDF9 and ZPI }\end{array}$ & [51] \\
\hline $\begin{array}{l}\text { hESC (XY) } \\
\text { hiPSC (XY) }\end{array}$ & $\begin{array}{l}\text { SSC medium } \\
\text { (MEM, } 0.2 \% \text { iFBS, bFGF) }\end{array}$ & Not analyzed & $\begin{array}{l}\text { H19 and IGF2 normal } \\
\text { imprinting patterns. }\end{array}$ & $\begin{array}{l}\text { Spermatogonia: } \\
\text { UTF1, PLZF, CDH1 } \\
\text { Spermatocyte: } \\
\text { HIWI/HILI }\end{array}$ & $\begin{array}{l}\text { Male germ cell, } \\
\text { (postmeiotic } \\
\text { spermatid-like cells) }\end{array}$ & [52] \\
\hline
\end{tabular}


Table 1. Continued

\begin{tabular}{|c|c|c|c|c|c|c|}
\hline Origin & Derivation conditions & In vivo assays & Epigenetic features & Germ cell markers & Outcome & Reference \\
\hline & & & & $\begin{array}{l}\text { 1N cells, Acrosin, } \\
\text { TNP1 and PRM1 }\end{array}$ & & \\
\hline $\mathrm{hESC}(\mathrm{XX}, \mathrm{XY})$ & hESC without bFGF; & Not analyzed & H19 methylation levels; & VASA, SYCP $3, \gamma H 2 A X$ & $\begin{array}{l}\text { Sperm-like } \\
\text { phenotype }\end{array}$ & [53] \\
\hline $\operatorname{hiPSC}(X X, X Y)$ & $\begin{array}{l}\text { RA, LIF, FRSK, bFGF, } \\
\text { CYP26 inhibitor. }\end{array}$ & & $\begin{array}{l}\text { CDKN1C, PHLDA2 } \\
\text { (maternal allele); }\end{array}$ & & & \\
\hline & & & $\begin{array}{l}\text { MEST, IGF2, NNAT, } \\
\text { SNRPN (paternal allele). }\end{array}$ & & & \\
\hline hESC (XX) & $\begin{array}{l}\text { EB and monolayer } \\
\text { differentiation }\end{array}$ & Not analyzed & $\begin{array}{l}\text { CpG sites of } H 19 / / G F 2 \\
\text { DMRs show a decrease } \\
\text { of methylation; }\end{array}$ & $\begin{array}{l}\text { SSEA1, VASA. STELLA, } \\
\text { OCT4, SCP1, SCP3. }\end{array}$ & Putative PGCs & [54] \\
\hline & & & $\begin{array}{l}\text { H3K4 dimethylation } \\
\text { increase; }\end{array}$ & & & \\
\hline & & & $\begin{array}{l}\text { H3K9 dimethylation } \\
\text { decrease }\end{array}$ & & & \\
\hline $\begin{array}{l}\text { Oogonial stem } \\
\text { cells }(X X)\end{array}$ & $\begin{array}{l}\text { Isolation by } \\
\text { immunomagnetic } \\
\text { sorting from human } \\
\text { ovarian cortical tissue. }\end{array}$ & $\begin{array}{l}\text { YES } \\
\text { (Oocyte generation) }\end{array}$ & Not analyzed & $\begin{array}{l}\text { VASA, KIT, BLIMP1, } \\
\text { STELLA, FRAGILIS, DAZL, } \\
\text { NOBOX, ZP1, ZP2, ZP3, } \\
\text { GDF9, DMC1, SYCP3. }\end{array}$ & Oocyte-like cells (1N) & [55] \\
\hline $\begin{array}{l}\text { Human hepatic } \\
\text { cell line } \\
(\text { HL7702) (X0) }\end{array}$ & $\begin{array}{l}\text { In vitro culture } \\
\text { differentiation to } \\
\text { PGC-like cells } \\
\text { (DMEM + 10\% FBS). }\end{array}$ & Not analyzed & Not analyzed & $\begin{array}{l}\text { AP, OCT4, C-KIT, } \\
\text { NANOS3, VASA, DAZL, } \\
\text { GDF9, SYCP3, ZP3 }\end{array}$ & $\begin{array}{l}\text { Follicle-like structure } \\
\text { Oocyte-like cells. } \\
\text { Spontaneous } \\
\text { embryo-like } \\
\text { structures }\end{array}$ & [56] \\
\hline $\begin{array}{l}\text { Human endometrial } \\
\text { cells }(X X)\end{array}$ & $\begin{array}{l}\text { Somatic cell } \\
\text { haploidization using } \\
\text { GV enucleated } \\
\text { mouse oocytes. }\end{array}$ & Not analyzed & Not analyzed & Not analyzed & Mll oocytes & [57] \\
\hline hESC, hiPSC (XX, XY) & $\begin{array}{l}\text { bFGF, ActA, BMP4 } \\
\text { 20\% KSR, BMP4, } \\
\text { LIF, ROCK inhibitor }\end{array}$ & $\begin{array}{l}\text { YES } \\
\text { (PGCLC Survive but } \\
\text { notprogress) }\end{array}$ & $\begin{array}{l}\text { PEG1,PEG10 } \\
\text { and NESP55; } \\
\text { Decreased in } \\
\text { methylation levels. }\end{array}$ & $\begin{array}{l}\text { OCT4, NANOG, SOX2, } \\
\text { BLIMP1, STELLA, } \\
\text { NANOS3, CKIT, T }\end{array}$ & PGCLCs & [14] \\
\hline $\begin{array}{l}\text { SSC (azoospermic } \\
\text { patients) }\end{array}$ & $\begin{array}{l}\text { Co-cultured with } \\
\text { Sertoli cells } \\
\text { KSR, FSH, } \\
\text { testosterone, } \\
\text { GDNF, RA. }\end{array}$ & Not analyzed & Not analyzed & $\begin{array}{l}\text { SCP3, CREST MLH1 } \\
\text { Haploid for } \\
\text { chromosomes } \\
\text { 13, 18, 21, X } \\
\text { and Y by FISH. }\end{array}$ & Meiotic-like cells & [45] \\
\hline $\begin{array}{l}\text { SSCs (cryptorchid } \\
\text { patients) }\end{array}$ & RA, SCF. & $\begin{array}{l}\text { YES } \\
\text { (Round spermatids } \\
\text { generated and ROSI) }\end{array}$ & Not analyzed & $\begin{array}{l}\text { SYCP1, SYCP3, ACR, } \\
\text { TNP1, TNP2, PRM1, } \\
\text { PRM2, BOULE, CREST, } \\
\text { DMC1 }\end{array}$ & $\begin{array}{l}\text { Haploid spermatids; } \\
\text { early embryos. }\end{array}$ & [58] \\
\hline
\end{tabular}

hESC, human embryonic stem cell; BMP, bone morphogenetic protein; RA, retinoic acid; ICR, imprinted control region; hiPSC, human induced pluripotent stem cell; PGC, primordial germ cell; PGCLC, PGC-like cell; LIF, leukemia inhibitory factor; EGF, epidermal growth factor; ROCK, Rho-kinase; NMT, neonatal mouse testes; bFGF, basic fibroblast growth factor; KSR, knockout serum replacement; FSH, follicle-stimulating hormone; GDNF, glial derived neurotrophic factor; SSC, spermatogonial stem cells; SCF, stem cell factor; ROSI, round spermatid injection. 
cells in humans were reported by spontaneous differentiation $[83,84]$ of hESCs embryoid bodies [51,54]. Undifferentiated hESCs expressed some early germ cell markers such as C-KIT and DAZL, but not later markers such as VASA (a RNA helicase involved in germ cell maturation in both sexes) or SYCP3 (a structural protein of the synaptonemal complex critical for meiosis) [85], suggesting that hESCs could be a heterogeneous pluripotent population in which some cells had a predisposition towards a germ cell fate. Addition of several molecules have been shown to improve the differentiation efficiency of pluripotent cells to germ cells, this is the case of BMP cytokines [51,52,56], and retinoic acid (RA) that has been demonstrated to induce meiosis $[15,50,86]$. However, meiotic progression remained as one of the main obstacles for artificial gametes derivation [87]; most of the works published to date report spontaneous differentiation towards putative PGCs or PGC-like cells (PGCLC) with diploid (2N) content of DNA (Table 1), but the completion of meiosis to give haploid ( $1 \mathrm{~N})$ cells remains a challenge when spontaneous differentiation is used.

In fact, complete meiotic progression of in vitro derived human germ cells was achieved by inducing the ectopic expression of the $D A Z$ gene family members (DAZ2, DAZL, and BOULE) not only in hESC but also in human iPSCs (hiPSCs) lines subjected to spontaneous differentiation $[46,47]$. The expression of these highly conserved RNAbinding proteins lead the correct meiotic progression of human germ cells in vitro in the absence of a gonadal niche. Also RNA-binding proteins, like VASA, could have a possible role in meiotic entry control [48]. A recent study have provided a more accurate process, in which pluripotent stem cells were first cultured in $4 \mathrm{i}$ conditions to induce the naiive pluripotent state, this step make cells prone to response to specification signals [88]. Then, the derivation process was performed in culture media supplemented with BMPs, leukemia inhibitory factor (LIF), Rho kinase (ROCK) inhibitor and Knockout serum replacement, to obtain the PGC precursors and then PGCLCs $[13,14]$. This system allows for the generation of large numbers of cells for use in research procedures. In summary, human artificial meiotic or sperm-like cells had been generated from both ESCs and iPSCs, assessed by the expression of meiotic and post-meiotic markers and DNA ploidy (Table 1).

On the female side, less studies have been performed with hESC and hiPSC for oocytes generation, partially due to the difficulties derived from the complexity of the own oocyte cell. Nonetheless previous data has shown that oocyte-like cells, expressing oocyte-specific markers, can be developed from ESCs and iPSCs [53,89-93]. These oocyte-like cells were developed from stem cells that expressed at least a degree of pluripotency, and the resulting oocyte-like cells expressed some germinal markers like the structural meiotic protein SYCP3 [90] as well as C-KIT, ZP1, ZP2, ZP3, VASA, and DMC1 [81] but were still far from being real and competent oocytes. Finally, the most challenged goal in the artificial gamete generation seems to be the production of sperm and eggs from the opposite sex. This would be of great importance to gay couples who wish to have genetically related offspring. However, little has been achieved in this direction and only a couple of papers reporting generation of sperm from female cells exist, albeit this sperm was not fully functional and presented incorrect or unknown epigenetic status $[94,95]$.

\section{Clinical use of artificial gametes in assisted reproductive treatments}

Human artificial gametes are likely to be developed in the following years and they hold a great hope for the treatment of unfertile patients devoid of gametes, allowing them to have genetically related progeny. However, clinical applications of in vitro derived gametes are unlikely to be used for therapeutic use until their fully functionality and safety will be guaranteed.

\section{Functionality of artificial sperm and eggs- viability and long- term health of derived offspring}

Determining functionality of derived gametes will, therefore, require establishing their capacity for fertilization and early embryogenesis. In order to consider artificial sperm for clinical purposes, they should be tested to be able to produce the main biological proceses leading to fertilization as the initiation of oocyte activation, nuclear remodelling and subsequent fusion to the oocyte nucleus, and loss of the own nuclear envelop [96]. On the other side, when artificially derived eggs needs to be assessed for clinical use they should be able to escape from meiotic arrest, undergo pronuclear formation, initiate embryonic gene activation while recapitulating nuclear maturation events (i.e., germinal vesicle breakdown, chromosomal segregation, polar body extrusion) and cytoplasmic reorganization (i.e., adenosine triphosphate (ATP) supply by mitochondria, protein and mRNA storage) [97]. Finally, to fully address the generation of functional artificial gametes they need to be proved to successfully give a healthy embryo upon fecundation, showing correct genetic and epigenetic reprogramming, cleavage divisions and zygotic genome activation [98].

Ethical restrictions make difficult to carry out functional assays in humans with germ cells obtained from stem cells. Moreover, differences in the pluripotent status of mESCs (naïve-like state) and hESCs (primed state) make difficult to compare their potential to fully develop into functional germ cells [99]. The main obstacle to develop fully committed sperm and eggs from stem cells is the lack of knowledge regarding molecules and factors, which are important in the gamete maturation process in the gonad niche and are not present when the immature gametes (OSC or SSC) are exposed to in vitro cul- 
ture conditions. For all these reasons, the functionality and safety of the obtained GCLC needs to be first tested in animal models.

\section{Transplantation of artificial PGC into animal models}

The most similar to functional assays are xenotransplantation of human germ cell-like cells into seminiferous tubules of immunosuppressed mice, in the male counterpart. These animal models are very helpful to test the ability of human germ cell-like cells to behave like human germ cell progenitors. In this context, the role of RNA-binding proteins has also been tested, demonstrating that hiPSCs improved their ability to colonize the lumen of the seminiferous tubules of sterilized immunodeficient mice upon VASA overexpression in combination with pluripotency factors. These results highlight the role of VASA in making cells competent to form germ cell development and in controlling the pluripotency-state in a combined in vitro/in vivo model [49].

This murine/human heterologous model represents a very interesting analysis method from a clinical point of view, and has already been used to analyze the ability of hiPSCs-GCLC derived from azoospermic men with different deletions in the $Y$ chromosome to colonize the spermatogonial niche, demonstrating how the genetic background affects their capability to differentiate into germ cells and colonize the seminiferous niche in vivo [49]. Finally, this same approach has been recently used to demonstrate that GCLC can be formed in vivo independently of X chromosome dosage [15]. In this case, hiPSCs from Turner syndrome patients were obtained, differentiated to GCLC and xenotransplanted into the seminiferous tubules of sterilized immunodeficient mice, demonstrating that the two $\mathrm{X}$ chromosomes are not required for human germ cell formation but for their maintenance until adulthood [15].

Also in vitro maturation of human oocytes is one of the most difficult tasks in the IVF programs. It has been proposed that transplantation of stem cells or stem cell-derived "oocytes" into the ovary or other organs would be of great advantage because it would provide a natural niche for maturation of oocytes and bypass several obstacles related to oocyte in vitro maturation [100]. In the mouse model it was confirmed that maturation of ESC-derived oocytes ultimately fails in vitro, and to overcome this obstacle the transplantation of ESC-derived oocyte-germ cells into an ovarian niche has been proposed to direct their natural and functional maturation. To demonstrate this, ESC-derived germ cells were enclosed into ovarian follicles, and some of them reached the primordial or primary stage of development after the two-step protocol by performing in vitro specification from $\mathrm{mESCs}$ and subsequent maturation in an in vivo model [100].

\section{Epigenetic remodelling in artificial gametes}

In 2006, the birth of murine offspring obtained by fertilization of murine oocytes with artificial mESCs-derived sperm was achieved [101] proving for the first time that stem cells could be developed in vitro to obtain autologous germ cells for reproductive treatments. However, the offspring presented phenotypic abnormalities as well as reduced life-span, mainly because of epigentic defects accumulated during germline in vitro specification and maturation [101]. Later on, Hayashi and collaborators reported the generation of healthy and fertile pups by fertilization of mouse oocytes with artificial sperm obtained by two-step differentiation of $\mathrm{mESC}$ through an intermediate epiblastic-like cells [102]. In this work, the authors assessed not only the cellular events and transcriptomics along the generation of gametes, but also their epigenetic profiles, showing that the in vitroderived germ cells closely resemble the physiological process [102], revealing the importance of the acquisition of a new epigenetic program in parallel to transcriptomic changes during differentiation from stem to germ cells. It has been also reported that erroneous epigentic imprinting can produce diseases in humans [103] enphasizing the relevance of epigenetics in the developmental process from germ cells to adult life.

As discussed before, one of the crucial facts in PGC specification is an extensive epigenetic remodeling. This epigenetic remodeling is mainly characterized by an overall reduction in DNA methylation during migration of PGCs to the gonadal ridge [22]. DNA methylation is a repressive mark that mainly targets cytosines within $\mathrm{CpG}$ islands (palindromic CpG dinucleotides in the genome) [24] producing a complete erase of the methylation patterns and thus the acquisition of totipotency in gametes of both sexes [104]. Then, during sex determination, PGCs must establish their sex-specific epigenetic patterns, which include paternal or maternal imprinted marks in order to acquire the epigenetic state necessary to form functional gametes [21]. The imprinting genes involve genomic sequences that exhibit differences in CpG methylation according to the parental origin. These differentially methylated regions (DMRs) can influence the allele-specific expression of one or more genes [21]. After fertilization, a second wave of epigenetic reprogramming is produced in all the genome but in the imprinted regions, which in turn regulates fetal and placental growth, differentiation, development and other important functions after birth [105].

It has been recently suggested that in vitro manipulation of cells could lead to epigenetic alterations affecting either stem cells or the obtained artificial gametes [106-109]. Not all the studies performed in the field have analyzed the epigenetic status of generated cells, but when authors assesed epigenetic features of these cells, they found similar patterns than their in vivo counterparts, with a sharp decrease in global methylation levels, and methylation patterns in DMRs of imprinting genes according to their fate $[46,48]$. Nonetheless, the correct epigenetic state of artificial gametes is an important 
issue that will determine the successful development of the offspring. Especial attention should be paid to the epigenetic analysis on DNA metyhlation and histone modification to ensure the complete imprimting of artificial gametes and avoid partially reprogrammed artifacts [53].

\section{Safety of artificial gametes}

Finally, the long-term safety of the obtained artificial gametes will be a critical issue to assess the quality and applicability of derived artificial gametes into the clinical practice. Observational and biochemical tests can be performed to demostrate the safety of artificial sperm or eggs, but these assays are insufficient to judge whether the cells would support normal development in humans upon fertilization until the adult life. The most robust and stringent studies reporting human PCGs generated in vitro have shown that these cells present normal germ cell genetic and epigenetic profiles and are able to colonize [14] and proliferate when xenotransplanted into mice testes $[15,49]$. However, some other works have reported incomplete imprinting of the generated germ-like cells [53]. These findings highlight the need for more consistent research that should be focused to the following main directions: (1) tumorigenicity of the cells as in vitro culture of stem cells for long periods as well as reprogramming of patient-specific somatic cells to hiPSCs have been shown to constitute risks factors for accumulation of chromosomal aneuploidies [110,111]; (2) immunogenicity of in vitro generated gametes, which remains a challenge for their use as potential progenitors to be transplanted into the host as they could produce immunological rejection problems even if they are used in autologous therapy, as it has been reported for some hiPSCs cell lines [112]; (3) the future use of artificial gametes in regenerative medicine programs would require the obtention of therapeutic grade sperm and eggs attending to strict production conditions that guarantee that these cells do not present additional risks acquired during their manipulation.

\section{Conclusion}

Generation of artificial gametes is a great promise for all those couples that, for many different reasons, currently need to go to gamete donation for fulfilling their wish to have children but would prefer to have genetically related offspring due to ethical, social or emotional reasons. Also, the successful generation of artificial gametes will help to understand the complex biological process of gametogenesis in humans, leading to the improvement in the knowledge and potential treatments of many disorders related to infertility and those diseases that are genetically transmitted to the progeny.

Despite the great interest that this field has arisen in the last years, there is still a long way to go until artificial germ cells will be used in the clinical practice. First, from the technological point of view, the accumulated knowlegde learnt from the mouse model needs to be translated to humans considering the important differences between both species. Once we are able to obtain germ cells in vitro from stem cells (either adult or pluripotent) the feasibility of using artificial sperm or oocytes for IVF treatments should be carefully analyzed attending to different criteria. In this regard, functionality and safety of artificial gametes needs to be assessed genetically and epigenetically to prove the health of the offspring derived from artifcial eggs or sperm.

\section{Conflict of interest}

No potential conflict of interest relevant to this article was reported.

\section{References}

1. Johnson AD, Richardson E, Bachvarova RF, Crother BI. Evolution of the germ line-soma relationship in vertebrate embryos. Reproduction 2011;141:291-300.

2. Kashir J, Jones C, Child T, Williams SA, Coward K. Viability assessment for artificial gametes: the need for biomarkers of functional competency. Biol Reprod 2012;87:114.

3. Sinha P, Kuruba N. Premature ovarian failure. J Obstet Gynaecol 2007;27:16-9.

4. Coulam CB, Adamson SC, Annegers JF. Incidence of premature ovarian failure. Obstet Gynecol 1986;67:604-6.

5. Jarow JP, Espeland MA, Lipshultz LI. Evaluation of the azoospermic patient. J Urol 1989;142:62-5.

6. Hwang K, Lamb DJ. New advances on the expansion and storage of human spermatogonial stem cells. Curr Opin Urol 2010; 20:510-4.

7. Levine J, Canada A, Stern CJ. Fertility preservation in adolescents and young adults with cancer. J Clin Oncol 2010;28:4831-41.

8. Silber SJ. Sperm retrieval for azoospermia and intracytoplasmic sperm injection success rates: a personal overview. Hum Fertil (Camb) 2010;13:247-56.

9. Woodruff TK. The Oncofertility Consortium: addressing fertility in young people with cancer. Nat Rev Clin Oncol 2010;7:466-75.

10. Wyns C, Curaba M, Vanabelle B, Van Langendonckt A, Donnez J. Options for fertility preservation in prepubertal boys. Hum Reprod Update 2010;16:312-28.

11. Jahnukainen K, Ehmcke J, Hou M, Schlatt S. Testicular function and fertility preservation in male cancer patients. Best Pract Res Clin Endocrinol Metab 2011;25:287-302.

12. Wallace WH. Oncofertility and preservation of reproductive capacity in children and young adults. Cancer 2011;117:2301-10. 
13. Irie N, Weinberger L, Tang WW, Kobayashi T, Viukov S, Manor YS, et al. SOX17 is a critical specifier of human primordial germ cell fate. Cell 2015;160:253-68.

14. Sugawa F, Arauzo-Bravo MJ, Yoon J, Kim KP, Aramaki S, Wu G, et al. Human primordial germ cell commitment in vitro associates with a unique PRDM14 expression profile. EMBO J 2015;34: 1009-24.

15. Dominguez AA, Chiang HR, Sukhwani M, Orwig KE, Reijo Pera RA. Human germ cell formation in xenotransplants of induced pluripotent stem cells carrying $X$ chromosome aneuploidies. Sci Rep 2014;4:6432.

16. Aramaki S, Hayashi K, Kurimoto K, Ohta H, Yabuta Y, Iwanari H, et al. A mesodermal factor, $T$, specifies mouse germ cell fate by directly activating germline determinants. Dev Cell 2013;27:51629.

17. Weber S, Eckert D, Nettersheim D, Gillis AJ, Schafer S, Kuckenberg $\mathrm{P}$, et al. Critical function of AP-2 gamma/TCFAP2C in mouse embryonic germ cell maintenance. Biol Reprod 2010;82:214-23.

18. Niwa H. How is pluripotency determined and maintained? Development 2007;134:635-46.

19. Aflatoonian B, Moore $H$. Human primordial germ cells and embryonic germ cells, and their use in cell therapy. Curr Opin Biotechnol 2005; 16:530-5.

20. Perrett RM, Turnpenny L, Eckert JJ, O'Shea M, Sonne SB, Cameron IT, et al. The early human germ cell lineage does not express SOX2 during in vivo development or upon in vitro culture. Biol Reprod 2008;78:852-8.

21. Hackett JA, Zylicz JJ, Surani MA. Parallel mechanisms of epigenetic reprogramming in the germline. Trends Genet 2012;28:16474.

22. Godin I, Wylie C, Heasman J. Genital ridges exert long-range effects on mouse primordial germ cell numbers and direction of migration in culture. Development 1990;108:357-63.

23. Seisenberger S, Andrews S, Krueger F, Arand J, Walter J, Santos F, et al. The dynamics of genome-wide DNA methylation reprogramming in mouse primordial germ cells. Mol Cell 2012;48: 849-62.

24. Lee HJ, Hore TA, Reik W. Reprogramming the methylome: erasing memory and creating diversity. Cell Stem Cell 2014;14:710-9.

25. Martinez-Arroyo AM, Medrano JV, Remohi J, Simon C. Germ line development: lessons learned from pluripotent stem cells. Curr Opin Genet Dev 2014;28:64-70.

26. Aguilar-Gallardo C, Poo M, Gomez E, Galan A, Sanchez E, Marques-Mari A, et al. Derivation, characterization, differentiation, and registration of seven human embryonic stem cell lines (VAL-3, -4, -5, -6M, -7, -8, and -9) on human feeder. In Vitro Cell Dev Biol Anim 2010;46:317-26.
27. Takahashi K, Yamanaka S. Induction of pluripotent stem cells from mouse embryonic and adult fibroblast cultures by defined factors. Cell 2006;126:663-76.

28. Takahashi K, Tanabe K, Ohnuki M, Narita M, Ichisaka T, Tomoda K, et al. Induction of pluripotent stem cells from adult human fibroblasts by defined factors. Cell 2007;131:861-72.

29. Yu J, Vodyanik MA, Smuga-Otto K, Antosiewicz-Bourget J, Frane $J$, Tian S, et al. Induced pluripotent stem cell lines derived from human somatic cells. Science 2007;318:1917-20.

30. Rompolas P, Greco V. Stem cell dynamics in the hair follicle niche. Semin Cell Dev Biol 2014;25-26:34-42.

31. Watt FM. Mammalian skin cell biology: at the interface between laboratory and clinic. Science 2014;346:937-40.

32. Wabik A, Jones PH. Switching roles: the functional plasticity of adult tissue stem cells. EMBO J 2015;34:1164-79.

33. Izadyar F, Wong J, Maki C, Pacchiarotti J, Ramos T, Howerton K, et al. Identification and characterization of repopulating spermatogonial stem cells from the adult human testis. Hum Reprod 2011;26:1296-306.

34. Kolasa A, Misiakiewicz K, Marchlewicz M, Wiszniewska B. The generation of spermatogonial stem cells and spermatogonia in mammals. Reprod Biol 2012;12:5-23.

35. Waheeb R, Hofmann MC. Human spermatogonial stem cells: a possible origin for spermatocytic seminoma. Int J Androl 2011; 34:e296-305.

36. Phillips BT, Gassei K, Orwig KE. Spermatogonial stem cell regulation and spermatogenesis. Philos Trans R Soc Lond B Biol Sci 2010;365:1663-78.

37. Hermann BP, Sukhwani M, Hansel MC, Orwig KE. Spermatogonial stem cells in higher primates: are there differences from those in rodents? Reproduction 2010;139:479-93.

38. Conrad S, Renninger M, Hennenlotter J, Wiesner T, Just L, Bonin $M$, et al. Generation of pluripotent stem cells from adult human testis. Nature 2008;456:344-9.

39. Kanatsu-Shinohara M, Toyokuni S, Shinohara T. CD9 is a surface marker on mouse and rat male germline stem cells. Biol Reprod 2004;70:70-5.

40. Kubota H, Avarbock MR, Brinster RL. Spermatogonial stem cells share some, but not all, phenotypic and functional characteristics with other stem cells. Proc Natl Acad Sci U S A 2003;100: 6487-92.

41. Ryu BY, Orwig KE, Kubota H, Avarbock MR, Brinster RL. Phenotypic and functional characteristics of spermatogonial stem cells in rats. Dev Biol 2004;274:158-70.

42. Buaas FW, Kirsh AL, Sharma M, McLean DJ, Morris JL, Griswold $M D$, et al. Plzf is required in adult male germ cells for stem cell self-renewal. Nat Genet 2004;36:647-52. 
43. Hofmann MC, Braydich-Stolle L, Dym M. Isolation of male germline stem cells; influence of GDNF. Dev Biol 2005;279:114-24.

44. von Schonfeldt V, Wistuba J, Schlatt S. Notch-1, c-kit and GFRalpha- 1 are developmentally regulated markers for premeiotic germ cells. Cytogenet Genome Res 2004;105:235-9.

45. Riboldi M, Rubio C, Pellicer A, Gil-Salom M, Simon C. In vitro production of haploid cells after coculture of CD49f+ with Sertoli cells from testicular sperm extraction in nonobstructive azoospermic patients. Fertil Steril 2012;98:580-90.e4.

46. Kee K, Angeles VT, Flores M, Nguyen HN, Reijo Pera RA. Human DAZL, DAZ and BOULE genes modulate primordial germ-cell and haploid gamete formation. Nature 2009;462:222-5.

47. Panula S, Medrano JV, Kee K, Bergstrom R, Nguyen HN, Byers B, et al. Human germ cell differentiation from fetal- and adult-derived induced pluripotent stem cells. Hum Mol Genet 2011;20: 752-62.

48. Medrano JV, Ramathal C, Nguyen HN, Simon C, Reijo Pera RA. Divergent RNA-binding proteins, DAZL and VASA, induce meiotic progression in human germ cells derived in vitro. Stem Cells 2012;30:441-51.

49. Durruthy Durruthy J, Ramathal C, Sukhwani M, Fang F, Cui J, Orwig $\mathrm{KE}$, et al. Fate of induced pluripotent stem cells following transplantation to murine seminiferous tubules. Hum Mol Genet 2014;23:3071-84.

50. Ramathal C, Durruthy-Durruthy J, Sukhwani M, Arakaki JE, Turek PJ, Orwig KE, et al. Fate of iPSCs derived from azoospermic and fertile men following xenotransplantation to murine seminiferous tubules. Cell Rep 2014;7:1284-97.

51. Aflatoonian B, Ruban L, Jones M, Aflatoonian R, Fazeli A, Moore HD. In vitro post-meiotic germ cell development from human embryonic stem cells. Hum Reprod 2009;24:3150-9.

52. Easley CAt, Phillips BT, McGuire MM, Barringer JM, Valli H, Hermann BP, et al. Direct differentiation of human pluripotent stem cells into haploid spermatogenic cells. Cell Rep 2012;2:440-6.

53. Eguizabal C, Montserrat N, Vassena R, Barragan M, Garreta E, Garcia-Quevedo L, et al. Complete meiosis from human induced pluripotent stem cells. Stem Cells 2011;29:1186-95.

54. Tilgner K, Atkinson SP, Golebiewska A, Stojkovic M, Lako M, Armstrong $L$. Isolation of primordial germ cells from differentiating human embryonic stem cells. Stem Cells 2008;26:3075-85.

55. White YA, Woods DC, Takai Y, Ishihara O, Seki H, Tilly JL. Oocyte formation by mitotically active germ cells purified from ovaries of reproductive-age women. Nat Med 2012;18:413-21.

56. Ma Z, Liu R, Wang X, Huang M, Gao Q, Lu Y, et al. Spontaneous germline potential of human hepatic cell line in vitro. Mol Hum Reprod 2013;19:216-26.

57. Palermo GD, Takeuchi T, Rosenwaks Z. Technical approaches to correction of oocyte aneuploidy. Hum Reprod 2002;17:2165-73.

58. Yang S, Ping P, Ma M, Li P, Tian R, Yang H, et al. Generation of haploid spermatids with fertilization and development capacity from human spermatogonial stem cells of cryptorchid patients. Stem Cell Reports 2014;3:663-75.

59. Block E. Quantitative morphological investigations of the follicular system in women; variations at different ages. Acta Anat (Basel) 1952;14:108-23.

60. Block E. A quantitative morphological investigation of the follicular system in newborn female infants. Acta Anat (Basel) 1953;17:201-6.

61. Baker TG. A Quantitative and Cytological Study of Germ Cells in Human Ovaries. Proc R Soc Lond B Biol Sci 1963;158:417-33.

62. Gougeon A, Chainy GB. Morphometric studies of small follicles in ovaries of women at different ages. J Reprod Fertil 1987;81: 433-42.

63. Richardson SJ, Senikas V, Nelson JF. Follicular depletion during the menopausal transition: evidence for accelerated loss and ultimate exhaustion. J Clin Endocrinol Metab 1987;65:1231-7.

64. Hansen KR, Knowlton NS, Thyer AC, Charleston JS, Soules MR, Klein NA. A new model of reproductive aging: the decline in ovarian non-growing follicle number from birth to menopause. Hum Reprod 2008;23:699-708.

65. Bendsen E, Byskov AG, Andersen CY, Westergaard LG. Number of germ cells and somatic cells in human fetal ovaries during the first weeks after sex differentiation. Hum Reprod 2006;21:30-5.

66. Forabosco A, Sforza C. Establishment of ovarian reserve: a quantitative morphometric study of the developing human ovary. Fertil Steril 2007;88:675-83.

67. Faddy MJ, Gosden RG, Gougeon A, Richardson SJ, Nelson JF. ACcelerated disappearance of ovarian follicles in mid-life: implications for forecasting menopause. Hum Reprod 1992;7:1342-6.

68. Faddy MJ, Gosden RG. A model conforming the decline in follicle numbers to the age of menopause in women. Hum Reprod 1996;11:1484-6.

69. Zuckerman. The number of oocytes in the mature ovary. Rec Prog Horm Res. 1951;6:63-108.

70. Zou K, Yuan Z, Yang Z, Luo H, Sun K, Zhou L, et al. Production of offspring from a germline stem cell line derived from neonatal ovaries. Nat Cell Biol 2009;11:631-6.

71. Tilly JL. Apoptosis and ovarian function. Rev Reprod 1996;1:16272.

72. Oatley J, Hunt PA. Of mice and (wo)men: purified oogonial stem cells from mouse and human ovaries. Biol Reprod 2012;86:196.

73. Vogel G. Reproductive biology. Potential egg stem cells reignite debate. Science 2012;335:1029-30.

74. Ghazal S. Oogonial stem cells: do they exist and may they have 
an impact on future fertility treatment? Curr Opin Obstet Gynecol 2013:25:223-8.

75. Johnson J, Canning J, Kaneko T, Pru JK, Tilly JL. Germline stem cells and follicular renewal in the postnatal mammalian ovary. Nature 2004;428:145-50.

76. Byskov AG, Faddy MJ, Lemmen JG, Andersen CY. Eggs forever? Differentiation 2005;73:438-46.

77. Eggan K, Jurga S, Gosden R, Min IM, Wagers AJ. Ovulated oocytes in adult mice derive from non-circulating germ cells. Nature 2006;441:1109-14.

78. Begum S, Papaioannou VE, Gosden RG. The oocyte population is not renewed in transplanted or irradiated adult ovaries. Hum Reprod 2008;23:2326-30.

79. Liu Y, Wu C, Lyu Q, Yang D, Albertini DF, Keefe DL, et al. Germline stem cells and neo-oogenesis in the adult human ovary. Dev Biol 2007;306:112-20.

80. Virant-Klun I, Zech N, Rozman P, Vogler A, Cvjeticanin B, Klemenc $P$, et al. Putative stem cells with an embryonic character isolated from the ovarian surface epithelium of women with no naturally present follicles and oocytes. Differentiation 2008;76:843-56.

81. Virant-Klun I, Skutella T, Hren M, Gruden K, Cvjeticanin B, Vogler A, et al. Isolation of small SSEA-4-positive putative stem cells from the ovarian surface epithelium of adult human ovaries by two different methods. Biomed Res Int 2013;2013:690415.

82. Szotek PP, Chang HL, Brennand K, Fujino A, Pieretti-Vanmarcke R, Lo Celso C, et al. Normal ovarian surface epithelial label-retaining cells exhibit stem/progenitor cell characteristics. Proc Natl Acad Sci U S A 2008;105:12469-73.

83. Clark AT, Bodnar MS, Fox M, Rodriquez RT, Abeyta MJ, Firpo MT, et al. Spontaneous differentiation of germ cells from human embryonic stem cells in vitro. Hum Mol Genet 2004;13:727-39.

84. Gkountela S, Li Z, Vincent JJ, Zhang KX, Chen A, Pellegrini M, et al. The ontogeny of cKIT+ human primordial germ cells proves to be a resource for human germ line reprogramming, imprint erasure and in vitro differentiation. Nat Cell Biol 2013;15:113-22.

85. Syrjanen JL, Pellegrini L, Davies OR. A molecular model for the role of SYCP3 in meiotic chromosome organisation. Elife 2014; 3:e02963.

86. Bowles J, Koopman P. Retinoic acid, meiosis and germ cell fate in mammals. Development 2007;134:3401-11.

87. Sun YC, Cheng SF, Sun R, Zhao Y, Shen W. Reconstitution of gametogenesis in vitro: meiosis is the biggest obstacle. J Genet Genomics 2014;41:87-95.

88. Gafni O, Weinberger L, Mansour AA, Manor YS, Chomsky E, BenYosef $D$, et al. Derivation of novel human ground state naive pluripotent stem cells. Nature 2013;504:282-6.

89. Hubner K, Fuhrmann G, Christenson LK, Kehler J, Reinbold R, De
La Fuente $R$, et al. Derivation of oocytes from mouse embryonic stem cells. Science 2003;300:1251-6.

90. Novak I, Lightfoot DA, Wang H, Eriksson A, Mahdy E, Hoog C. Mouse embryonic stem cells form follicle-like ovarian structures but do not progress through meiosis. Stem Cells 2006;24:19316.

91. West FD, Machacek DW, Boyd NL, Pandiyan K, Robbins KR, Stice SL. Enrichment and differentiation of human germ-like cells mediated by feeder cells and basic fibroblast growth factor signaling. Stem Cells 2008;26:2768-76.

92. West FD, Roche-Rios Ml, Abraham S, Rao RR, Natrajan MS, Bacanamwo $\mathrm{M}$, et al. KIT ligand and bone morphogenetic protein signaling enhances human embryonic stem cell to germ-like cell differentiation. Hum Reprod 2010;25:168-78.

93. Richards M, Fong CY, Bongso A. Comparative evaluation of different in vitro systems that stimulate germ cell differentiation in human embryonic stem cells. Fertil Steril 2010;93:986-94.

94. Kerkis A, Fonseca SA, Serafim RC, Lavagnolli TM, Abdelmassih S, Abdelmassih $\mathrm{R}$, et al. In vitro differentiation of male mouse embryonic stem cells into both presumptive sperm cells and oocytes. Cloning Stem Cells 2007;9:535-48.

95. Kono T, Obata Y, Wu Q, Niwa K, Ono Y, Yamamoto Y, et al. Birth of parthenogenetic mice that can develop to adulthood. Nature 2004;428:860-4.

96. Publicover S, Harper CV, Barratt C. [Ca2+]i signalling in sperm: making the most of what you've got. Nat Cell Biol 2007;9:23542.

97. Li Q, McKenzie L, Matzuk MM. Revisiting oocyte-somatic cell interactions: in search of novel intrafollicular predictors and regulators of oocyte developmental competence. Mol Hum Reprod 2008;14:673-8.

98. Niakan KK, Han J, Pedersen RA, Simon C, Pera RA. Human preimplantation embryo development. Development 2012;139: 829-41.

99. Magnusdottir E, Surani MA. How to make a primordial germ cell. Development 2014;141:245-52.

100. Nicholas CR, Haston KM, Grewall AK, Longacre TA, Reijo Pera RA. Transplantation directs oocyte maturation from embryonic stem cells and provides a therapeutic strategy for female infertility. Hum Mol Genet 2009;18:4376-89.

101. Nayernia K, Nolte J, Michelmann HW, Lee JH, Rathsack K, Drusenheimer $\mathrm{N}$, et al. In vitro-differentiated embryonic stem cells give rise to male gametes that can generate offspring mice. Dev Cell 2006;11:125-32.

102. Hayashi K, Ogushi S, Kurimoto K, Shimamoto S, Ohta H, Saitou M. Offspring from oocytes derived from in vitro primordial germ cell-like cells in mice. Science 2012;338:971-5. 
103. Grossniklaus U, Kelly WG, Ferguson-Smith AC, Pembrey M, Lindquist $S$. Transgenerational epigenetic inheritance: how important is it? Nat Rev Genet 2013;14:228-35.

104. Allegrucci C, Thurston A, Lucas E, Young L. Epigenetics and the germline. Reproduction 2005;129:137-49.

105. Messerschmidt DM, Knowles BB, Solter D. DNA methylation dynamics during epigenetic reprogramming in the germline and preimplantation embryos. Genes Dev 2014;28:812-28.

106. Geijsen N, Horoschak M, Kim K, Gribnau J, Eggan K, Daley GQ. Derivation of embryonic germ cells and male gametes from embryonic stem cells. Nature 2004;427:148-54.

107. Hajkova P, Erhardt S, Lane N, HaafT, El-Maarri O, ReikW, et al. Epigenetic reprogramming in mouse primordial germ cells. Mech Dev 2002;117:15-23.

108. Manipalviratn S, DeCherney A, Segars J. Imprinting disorders and assisted reproductive technology. Fertil Steril 2009;91:30515.

109. Hiura H, Okae H, Miyauchi N, Sato F, Sato A, Van De Pette M, et al. Characterization of DNA methylation errors in patients with imprinting disorders conceived by assisted reproduction technologies. Hum Reprod 2012;27:2541-8.

110. Ben-David U, Benvenisty N. The tumorigenicity of human embryonic and induced pluripotent stem cells. Nat Rev Cancer 2011;11:268-77.

111. Amps K, Andrews PW, Anyfantis G, Armstrong L, Avery S, Baharvand $\mathrm{H}$, et al. Screening ethnically diverse human embryonic stem cells identifies a chromosome 20 minimal amplicon conferring growth advantage. Nat Biotechnol 2011;29:1132-44.

112. Zhao T, Zhang ZN, Rong Z, Xu Y. Immunogenicity of induced pluripotent stem cells. Nature 2011;474:212-5. 